\title{
NEWS FROM FOREIGN RESEARCH INSTITUTES
}

\section{CENTRE FOR DEVELOPMENT RESEARCH, (formerly INSTITUTE FOR DEVELOPMENT RESEARCH), COPENHAGEN, DENMARK}

The Centre for Development Research is an independent institution under the Ministry of Foreign Affairs. The task of the Centre shall be, in collaboration with other research institutions, to collect documentation, keep abreast of current development research, in Denmark and abroad, and to assist in the implementation of research projects under the auspices of the Research Council for Development Research (Act of Parliament No. 145, March, 1976).

The Research Council is appointed by the Minister for Foreign Affairs. On the recommendation of the Council of Ministers grants subsidies to research relating to developing countries. The funds for this purpose are 2.5 mill. D.kr. for $1976 / 77$.

CDR has been allocated 1.2 mill. $\mathrm{kr}$. for $1976 / 77$ for its administration, library and support to research projects. These projects are financed by the Research Council alongside of other institutional or individual projects in Denmark.

The Centre is cooperating with other development research efforts in Denmark. A special link to the Copenhagen School of Economics and Business Administration is being established.

The following research projects are attached to the CDR:

\section{Rural Employment in Nyanza, Kenya}

Research fellows: John Carlsen and Tony Moody.

Expected completion: January 1st, 1977.

In cooperation with the Institute for Development Studies, Nairobi and the ILO, Geneva.

\section{Production of Means of Production for Agricultural Development: A Technology Assessment}

Research fellow: Jens Muller.

Expected completion: April 1st, 1978.

In cooperation with Small Industries Development Organization, Dar es Salaam.

Development of Peasant Communities with Special Reference to Tanzania

Research fellow: Jannik Boesen.

Expected completion: April 1st, 1978.

In cooperation with the Tanzania Rural Development Bank, Dar es Salaam.

The Subsistence Economy and the Women (Ghana)

Research fellow: Jette Bukh.

Expected completion: April 1st, 1977.

In cooperation with ISSER and the Institute of Adult Education, Legon University, Ghana.

\section{Basic Conditions of Rural Business in Kenya}

Research fellow: Per Kongstad.

Expected completion: July 1st, 1977.

In cooperation with the Ministry of Finance and Planning, Nairobi.

Rural Policy Implementation in Kenya, Tanzania and Zambia: A Comparative Study

Research fellow: Phil Raikes.

Expected completion: April 1st, 1978.

New projects are under preparation to start in 1977.

CDR operates a scheme of guest researchers.

CDR publishes a quarterly journal in Danish, Den $N y$ Verden.

CDR runs a small program of seminars and guest lectures.

A complete list of papers and publications for the Centre (and its predecessor the Institute for Development Research) $1969-76$ is available. More detailed information is also available in the annual reports. Write: Professor Knud Erik Svendsen, Director, Centre for Development Research, V. Voldgad 104, DK-1552 Copenhagen V., Denmark.

\section{INSTITUTE OF AFRICAN STUDIES, UNIVERSITY OF NAIROBI, KENYA}

The Institute of African Studies (formerly the Cultural Division, Institute for Development 
Studies) was established at the University of Nairobi, in October, 1965, for the purpose of initiating and directing research on cultural problems relating to the overall development of Kenya and East Africa generally. Related functions are to promote and coordinate inter-disciplinary research programmes; to provide research opportunities and experience for East African students interested in academic careers; to develop instructional materials for university and other teaching purposes, and to provide a centre with which research workers from other countries of Africa and overseas may be associated.

The Institute is primarily interested in promoting and conducting research in such fields as indigenous African prehistory and history, ethnography and social anthropology; modern and historical linguistics; musicology and dance; traditional and modern literature; traditional and modern arts and crafts; religions and other belief-systems.

RESEARCH ASSOCIATES. The Institute is eager to assist and keep in touch with scholars from other universities with research interests in cultural fields. Persons planning to conduct such research in Kenya are encouraged to apply for formal association with the Institute as "Research Associates." Services provided by the Institute under such associateship include: sponsorship and processing of the required authorization from the Office of the President in order to conduct research in Kenya; when resources permit, general secretarial assistance, such as forwarding of mail, typing, and duplication of short reports and discussion papers; use of the University Library and access to xerox, and machineprocessing services at University rates; University Senior Common Room privileges; in the case of predoctoral students, informal local supervision of field research if required; information on research facilities and organizations in Kenya and East Africa.

Persons intending to associate formally with the Institute are asked to agree to undertake the following obligations:

a. To send, at least three months in advance, a brief statement of their intended research program including information on its duration and probable or existing external/internal sponsorship, its aims and methodology; and any specific archives/records to be studied, or officials to be interviewed;

b. To make available to the Institute a seminar report on their preliminary research findings no later than six months after initiating research, and another report of research accomplishments at the end of their research period;

c. All predoctoral Research Associates will be assigned to a specific Institute Supervisor and will be required to keep such person fully informed at least once each month of all activities connected with their research program;

d. To cooperate, when practicable and specifically requested by Institute Fellows, in the collections of research data and materials for the Institute, especially for Institute priority projects (not necessarily in their own field);

e. To give due acknowledgement of any assistance received from the Institute in any publications based on research conducted during the period of associateship; and, in compliance with existing government regulations to provide the Institute (for forwarding to the university librarian) with a copy of any reports or publications or dissertations arising from their research, within three months of their completion;

f. To pay an Affiliation Fee of K.sh. 5,000/-per annum at the time of appointment to cover the cost of services provided.

Applications for "Research Associateship" should be sent to the Administrative Assistant, Institute of African Studies, University of Nairobi, P.O. Box 30197, Nairobi, Kenya, ideally at least three months in advance, in order to avoid delays in securing research clearance and associateship status.

\section{RESEARCH PROJECTS AT THE INSTITUTE}

The Institute of African Studies has defined specific projects which are locally regarded as having high priority research needs; seven such projects have been approved by the Institute Board. Each is supervised by a full-time member of the staff and all research fellows and associates will be required to carry out their research within these flexible fields.

Archaeological Survey and "Salvage" (Dr. Osaga Odak of the National Museuin of Kenya): the provision of services and assistance in coordinating effort to discover, evaluate and make more generally known archaeological sites (some of which might easily be destroyed by natural causes or by uninformed human intervention);

Art (Mr. Francis X. Nnaggenda left in October, 1974): the collection of traditional items and the encouragement and creation of contemporary sculpture, carving, and painting;

Belief Systems (Mr. Okot p'Bitek, left on Octover 31, 1974): the collection and study of various groups; traditional cosmogonies, social values, religious beliefs, myths, legends, and management of environment generally;

History (Professor Bethwell A. Ogot, Director of the Institute): the collection and recording, collating, analysing and writing up of history of all peoples from all possible sources, including especially oral and archaeological; 
Linguistics (Dr. John C. Sharman, left in December 1973) : collection of selected lexical items, the recording of grammatical systems with the double aim of obtaining better historical perspectives from glottochronology and starred forms, and of making modern descriptive analyses;

Material Culture (Mrs. E.J. Brown, left on June 30, 1974): the collection and classification of artifacts, the study of pottery-making, metal-working, and design;

Music (Mr. H. Owuor Anyumba, left on June 30, 1974): the collecition (recording and transcription) of traditional and "neo-traditional" songs, instrumental music and dance; also the classifying of musical instruments.

Other research projects at the Institute include:

\section{Belief Systems}

J.C. Palmer, B.S.C., Ph.D. candidate, London School of Economics: Urban-rural relations and entrepreneurship in Kenya.

Carole Scherrer, M.A., Ph.D. candidate, University of Virginia: A social structural analysis of the Elmolo.

Dirk Berg-Schlosser, Ph.D. candidate, Berkeley: Belief systems and differential economic development in Kenya.

Eugene Burt, B.A., M.A., Ph.D. candidate, University of Washington: The effects of modernization on the traditional arts of the eastern Luyia.

Elliot M. Fratkin, M.A., Ph.D. candidate, University of London: The world view of the Samburu-an interpretation of religious symbolism.

David J. Vick, M.A., Ph.D. candidate, Cambridge University: An investigation of the contemporary influence of Christian mission upon the social and religious institutions of the Luhya people.

History

George Mathu, M.A., Research Fellow, Institute of African Studies, University of Nairobi: A sociohistorical study of the early Christian converts and colonial chiefs in Kiambu District.

Stanley W. Liszka, Jr., M.A., Ph.D. candidate, Boston University: History of Voi township and to clarify the prehistorical movements of the Taita people based upon historical linguistics.

\section{Linguistics}

Charles Pike, M.A., Ph.D. candidate, University of Wisconsin/Madison: Luhya narrative art forms.

Robert A. Leonard, M.A., Ph.D. candidate, Columbia University: A study of the Swahili dialects of the northern Kenya coast.

Music

P.N. Kavyu, Junior Research Fellow, Institute of African Studies, University of Nairobi: Folk music and dance.

[This information was excerpted from Mila, issued by the Institute of African Studies, University of Nairobi, Vol IV., No. 2., 1974.]

THE RURAL DEVELOPMENT STUDIES BUREAU, UNIVERSITY OF ZAMBIA, LUSAKA, ZAMBIA

The Rural Development Studies Bureau of the University of Zambia was established in 1972 to conduct socio-economic research on the problems affecting the development of rural areas. It is currently engaged in studies of smallholder settlement schemes as a strategy for rural development, an 
evaluation of Farmer Training Centres (sponsored by the World Bank), field studies of labor use in agriculture and the prospects for rural sector employment, and a research project on development administration. The administration research project is being carried out in association with the Free University of Amsterdam and the National Institute for Public Administration. In addition, a survey is being initiated of the supply and marketing of horticultural products in the Lusaka area.

Facilities exist for overseas research scholars and graduate students to become affiliated with the Bureau to carry out research in Zambia. Rural development specialists may also be interested in the Bureau's publications, which include a comparative analysis of two cooperative unions in northern Zambia and a study of income and expenditure patterns of some farm households in the Southern Province.

Further information on the Bureau's activities may be obtained from Professor David H. Evans, Director, Rural Development Studies Bureau, P.O. Box 900, Lusaka, Zambia.

[This information was obtained from the Rural Development Network Bulletin, issued by the Overseas Liaison Committee of the American Council on Education, No. 4, November 1975, p. 15.]

\section{CONFLICT IN INTERNATIONAL RELATIONS FELLOWSHIPS}

THE ROCKEFELLER FOUNDATION announces the continuation of its fellowship program in the field of international relations for 1976-77. The program annually supports approximately twenty individuals from a variety of countries academic disciplines, and institutional affiliations.

The program has three principal objectives:

1. To identify and assess the critical and emerging issues which are likely to shape the international community in the decade ahead. Four types of issues will receive special emphasis.

- the development of a more viable world economy responsive to the growing need to redress the global disparities of wealth and income; the depletion of scarce resources; the intensifying competition to protect access to external supplies; the diffusion of power among states and transnational corporate actors; and changes in international capital markets;

- the quest for arms control in a multipolar world where progress toward the establishment of quantitative limits can become dangerously undermined by technological advances; where the traditional categories for defining weapons in arms control negotiotions-strategic/tactical, nuclear/conventional-are increasingly inadequate; and where nuclear proliferation and the burgeoning world trade in military equipment threaten international peace and security;

- the need for more effective international arrangements in order to reduce the risks of conflict arising from instability of the food-population-climate equation; and

- the possibilities for reducing international tension in specific conflict situations, bilateral and multilateral, where carefully designed research projects promise new insights.

2. To encourage fresh thinking about sources of conflict in an interdependent world and the capabilities of contemporary societies for coping with emerging conflict. Research and analysis that serve this objective would include:

- examination of the changing relationship between domestic and foreign policies in an international system attempting to respond to interdependence;

- consideration of measures for strengthening of international institutions and/or the creation of new arrangements (including early warning and fact-finding systems) that could affect the anticipation, management, and resolution of international conflict; and

- analyses of alternative means of terminating or de-escalating destructive conflict by promoting peaceful change.

3. To help develop the additional expertise in the above areas needed to improve policymaking and to better inform the public through the dissemination of materials of use to opinion leaders and in teaching programs

Fellowships are usually awarded for a one-year period. Each grant will vary in amount, depending upon individual circumstances, although grants do not normally exceed $\$ 30,000$ and most are well below that figure. While there are no specific eligibility criteria, previous experience or a demonstrated 
evaluation of Farmer Training Centres (sponsored by the World Bank), field studies of labor use in agriculture and the prospects for rural sector employment, and a research project on development administration. The administration research project is being carried out in association with the Free University of Amsterdam and the National Institute for Public Administration. In addition, a survey is being initiated of the supply and marketing of horticultural products in the Lusaka area.

Facilities exist for overseas research scholars and graduate students to become affiliated with the Bureau to carry out research in Zambia. Rural development specialists may also be interested in the Bureau's publications, which include a comparative analysis of two cooperative unions in northern Zambia and a study of income and expenditure patterns of some farm households in the Southern Province.

Further information on the Bureau's activities may be obtained from Professor David H. Evans, Director, Rural Development Studies Bureau, P.O. Box 900, Lusaka, Zambia.

[This information was obtained from the Rural Development Network Bulletin, issued by the Overseas Liaison Committee of the American Council on Education, No. 4, November 1975, p. 15.]

\section{CONFLICT IN INTERNATIONAL RELATIONS FELLOWSHIPS}

THE ROCKEFELLER FOUNDATION announces the continuation of its fellowship program in the field of international relations for 1976-77. The program annually supports approximately twenty individuals from a variety of countries academic disciplines, and institutional affiliations.

The program has three principal objectives:

1. To identify and assess the critical and emerging issues which are likely to shape the international community in the decade ahead. Four types of issues will receive special emphasis.

- the development of a more viable world economy responsive to the growing need to redress the global disparities of wealth and income; the depletion of scarce resources; the intensifying competition to protect access to external supplies; the diffusion of power among states and transnational corporate actors; and changes in international capital markets;

- the quest for arms control in a multipolar world where progress toward the establishment of quantitative limits can become dangerously undermined by technological advances; where the traditional categories for defining weapons in arms control negotiotions-strategic/tactical, nuclear/conventional-are increasingly inadequate; and where nuclear proliferation and the burgeoning world trade in military equipment threaten international peace and security;

- the need for more effective international arrangements in order to reduce the risks of conflict arising from instability of the food-population-climate equation; and

- the possibilities for reducing international tension in specific conflict situations, bilateral and multilateral, where carefully designed research projects promise new insights.

2. To encourage fresh thinking about sources of conflict in an interdependent world and the capabilities of contemporary societies for coping with emerging conflict. Research and analysis that serve this objective would include:

- examination of the changing relationship between domestic and foreign policies in an international system attempting to respond to interdependence;

- consideration of measures for strengthening of international institutions and/or the creation of new arrangements (including early warning and fact-finding systems) that could affect the anticipation, management, and resolution of international conflict; and

- analyses of alternative means of terminating or de-escalating destructive conflict by promoting peaceful change.

3. To help develop the additional expertise in the above areas needed to improve policymaking and to better inform the public through the dissemination of materials of use to opinion leaders and in teaching programs

Fellowships are usually awarded for a one-year period. Each grant will vary in amount, depending upon individual circumstances, although grants do not normally exceed $\$ 30,000$ and most are well below that figure. While there are no specific eligibility criteria, previous experience or a demonstrated 
research ability-normally a Ph.D. plus publications-in areas related to the focus of the fellowship program, is likely to minimally necessary if an applicant's proposal is to be competitive. Special consideration will also be given to applicants with relevant practical work experience in the conduct of international relations. The Fellowship Advisory Committee meets twice each year, in January and June. Deadlines for submission are December 1 and May 1, respectively. For further information, write: Conflict in International Relations Fellowships, The Rockefeller Foundation, 1133 Avenue of the Americas, New York, N.Y. 10036 . Telephone: (212) 869-8500.

\section{Newsletter contributors are advised that} the copy deadline for the December Newsletter is November 6, 1976.

\section{PUBLICATIONS}

The Black Studies Program of the University of Colorado at Boulder has announced the forthcoming publication, in a new series, of Umoja. It will be published three times a year and the first issue is scheduled to appear in January 1977.

Multidisciplinary in scope, Umoja is intended to encourage a rigorous and systematic investigation of issues in every field of knowledge concerning African peoples around the world. Studies from a comparative perspective and those that deal with methodological principles for Black Studies as a discipline are especially welcome. Contributions should be in the form of scholarly articles or review essays (shorter book reviews can also be submitted) and should not exceed 30 pages.

All correspondence should be addressed to: The Editor, Umoja, Black Studies Program, University of Colorado, Boulder, Colorado 80309 . Subscription rates: $\$ 12.00$ (individuals), $\$ 15.00$ (institutions).

Scholarly Press has announced the publication of the first volume of its 18-volume World Encyclopedia of Black Peoples.

Volume one, which provides an overview, consists of twenty articles by prominent black scholars. The second volume, now in preparation, consists of a "Chronology of Black America" and a "Chronology of Black Africa." Volumes three-sixteen are organized on the $A$ to $Z$ pattern. The final two volumes will consist of a bibliography and an index.

Upon completion the set, which is aimed at the library market, will sell for $\$ 600.00$. For further information,: write: Scholarly Press, Inc., 22929 Industrial Drive East, St. Clair Shores, Michigan 48080.

Okike, an African journal of new writing edited by Chinua Achebe, moved to Nigeria in July. The new address is P.O. Box 53, Nsukka, Nigeria.

Wanted as soon as possible-1,000 to 3,000 very good/excellent quality $35 \mathrm{~mm}$. color slides of single ethnic group in Africa from which 300 will be selected for use in a major publisher's anthropological/educational film strip or sufficient quantity of excellent quality slides on which to base possible assignment to photograph single ethnic group to script specifications. Contact: Judith Posner, 22 Old Orchard Road, Port Chester, New York 10573, telephone-(914) 937-1529, or, Seth Reichlin, Community Studies Project, 900 West End Avenue, Apt. 17-H, New York, N.Y. 10025, telephone(212) $662-3741$ or (212) $666-1484$. 